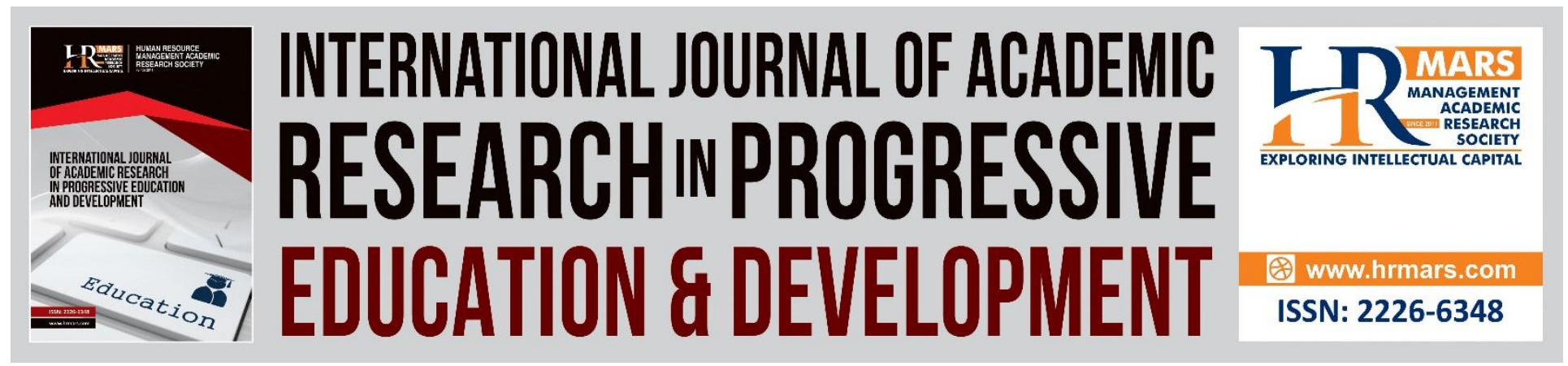

\title{
Islamic Perspectives: Using New Media in Education
}

\author{
Juritah Misman, Muhammad Taufik Md Sharipp, S. Salahudin Suyurno, \\ Sumayyah Shaidin
}

To Link this Article: http://dx.doi.org/10.6007/IJARPED/v8-i1/5269

DOI: $10.6007 /$ IJARPED/v8-i1/5269

Received: 17 Dec 2018, Revised: 28 Jan 2019, Accepted: 30 Jan 2019

Published Online: 10 Feb 2019

In-Text Citation: (Misman, Sharipp, Sharipp, \& Shaidin, 2019)

To Cite this Article: Misman, J., Sharipp, M. T. M., Sharipp, M. T. M., \& Shaidin, S. (2019). Islamic Perspectives: Using New Media in Education. International Journal of Academic Research in Progressive Education and Development, 9(1), 12-21.

Copyright: (c) 2019 The Author(s)

Published by Human Resource Management Academic Research Society (www.hrmars.com)

This article is published under the Creative Commons Attribution (CC BY 4.0) license. Anyone may reproduce, distribute, translate and create derivative works of this article (for both commercial and non-commercial purposes), subject to full attribution to the original publication and authors. The full terms of this license may be seen at: http://creativecommons.org/licences/by/4.0/legalcode

Vol. 8, No. 1, 2019, Pg. 12 - 21

http://hrmars.com/index.php/pages/detail/IJARPED

JOURNAL HOMEPAGE

Full Terms \& Conditions of access and use can be found at http://hrmars.com/index.php/pages/detail/publication-ethics 


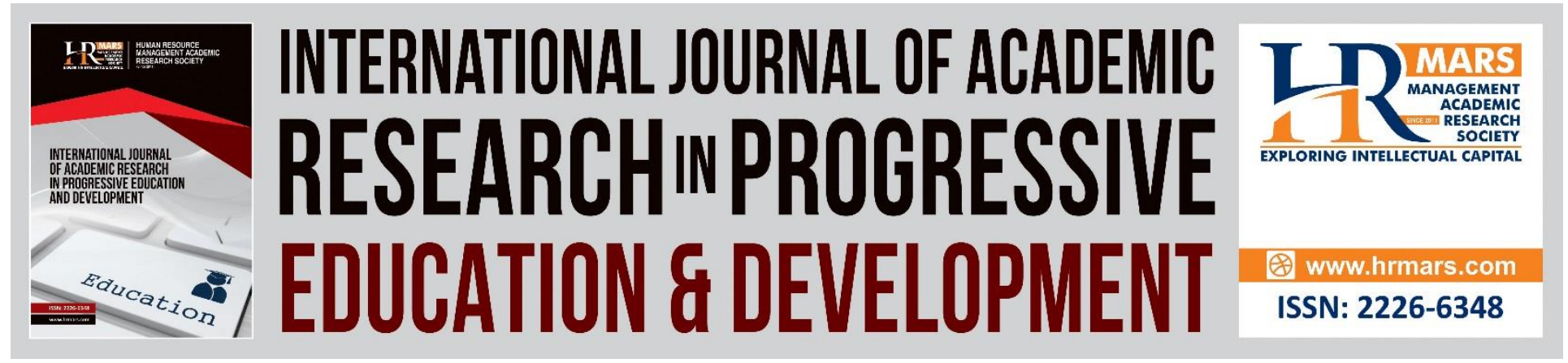

\title{
Islamic Perspectives: Using New Media in Education
}

\author{
${ }^{1} J u r i t a h$ Misman, ${ }^{2}$ Muhammad Taufik Md Sharipp, \\ ${ }^{2}$ S. Salahudin Suyurno, ${ }^{1}$ Sumayyah Shaidin \\ ${ }^{1}$ Academy of Language Studies, UiTM Melaka, ${ }^{2}$ Centre of Islamic Studies, UiTM Melaka \\ Malaysia
}

\begin{abstract}
New media such as smartphones, social media, computers, virtual world, single media, and online games are dominantly used in the modern world. In fact, current education scenario advocates the use of the new media in the teaching and learning processes. The positivity of using new media is limitless but not without risks and challenges. Nevertheless, Islam has outlined that Muslims should uphold knowledge and guidance from truthful sources of knowledge such as the Qur'an and Hadith to prevent them from becoming deviant users of the new media. The main objective of this paper is to present the Islamic perspectives in terms of the benefits, challenges, and moral ethics of using the new media in education and also in the society in general, so that contemporary users of the new media technology have the knowledge which can guide them to embrace the transformation responsibly and humbly.
\end{abstract}

Keywords: New Media, Islamic Perspectives, Challenges, Advantages, Ethics, Guidance

\section{Introduction}

In the modern world, the onrush of new media and digital technology has transformed almost all aspects of our life including information, communication, education, entertainment, politics, administration, security, traveling, economic and finance. Advanced technology has changed ways we communicate, entertain, learn, deliver and exchange knowledge and information and other tasks to become more efficient and instantaneous. Under these circumstances, people's beliefs, cultures, attitudes, behaviours, values, and perspectives about the world have been transformed (Saifee et al, 2012; Ramlan \& Ridzuan, 2016). Most importantly, people nowadays conduct businesses, entertain and study using the internet; even governments around the world administer and connect with their citizens using online websites as part of their approaches. People can share any forms of texts, audio and videos with other users. Manap (2016) concluded that social media and the advancement of technology posed more complex and challenging issues for the society and educators. 


\section{New Media and Education}

Currently, new social media platforms such as Facebook, WhatsApp, WeChat, Twitter and Telegram have made teaching and learning, communicating, sharing and anything related to online communication to become more powerful. Manap et al. (2016) in their research on the usage of social media amongst generation $Z$ students in Malaysia found that their respondents highly used the social media platforms comprising of Instagram, followed by Facebook and Twitter and WeChat and they moderately used WhatsApp, Blogs, YouTube and Telegram.

New media has its own potentials in terms of Islamic education and teachings. Digital media technology can be used for education purposes and to transmit knowledge pertaining to Islam and its teachings. Saifee (2012) suggested several innovative ideas about using the media technology to spread the message of Islam and good human values such as using relevant television channels such as programmes, game shows, plays, talks and cartoons, websites, ICT such as multimedia and video presentations, to be adapted in the classrooms. For example, people from different parts of the world can access Islamic information and other teachings from of great scholars from live or recorded talks and participate with them by giving questions and feedbacks online. Saifee (2012) further conceded that Islam can arise with efforts to spread Islam and its teachings using the tools of media technology.

In contrast, there are several risks of using the new media among students. Young student respondents claimed that they use the social media at long interval duration every day, up to 11.6 hours to 24 hours (Manap et al., 2016). For example, Instagram is widely used by them to upload their daily activities in video and picture forms. In other words, these students diligently use the internet and social media platforms for long hours daily to get information, exchange knowledge, build networking, record and document their daily activities, and make instantaneous communication. This surely affects their academic performance as they focus more on irrelevant social media activities than their study. Thus, this shows that social media platforms may bring positive and negative implications towards youngsters.

\section{Challenges and Risks of Using New Media in Teaching and Learning}

As a contemporary medium for teaching and learning, users are exposed to various challenges and risks when using new media platforms. Among the arising issues are:

\section{Wasting time on social media platforms and ignoring academic and social responsibilities.}

Islam urges that individuals should use technology for honest and humble reasons. Therefore, users especially students must not use the new media for negative reasons such as spending too much time on social media to insult, gossip, and highlighting to others online about their emotions, moods, and problems negatively. Some even disregard their families, friends and teachers when they are too obsessed with their virtual world activities. Unfortunately, some even use the time in classes and in schools to access and use their social media platforms and post their selfies from there, purely for fun and entertainment reasons. 


\section{Content may contain sensitive matters.}

Sensitive matters such as issues on religious propaganda, racism, and others if used in classrooms may trigger sparks of enmity between religions or ethnicities especially in Malaysia which is a multi-racial and multi-religious nation.

\section{The overflow of information which is not controlled causes users to have difficulties in determining its validity.}

In Islam, the concept of education is mutawatir or in stages. However, the tsunami of information from the use of the digital media today has resulted in the dumping of information to its users without any restriction, control, or time. Therefore, those who are ignorant and do not know the root cause of something would continue to interpret and make their own conclusions. In Malaysia, there are lack of relevant policies, effective measures, and monitoring by authoritative bodies. Therefore, information that is circulated amongst digital media users are not being filtered and organized properly. True and false information and news hover around users without any boundaries. Hence, it is important that the government educate users of the new media on how to filter information disseminated through social media.

\section{Declining acts of courtesy of students towards their teachers.}

The acts of courtesy towards teachers are slowly fading. Islam emphasizes that students place high regards towards teachers as counsellors, experts, and advisors. With the use of current and sophisticated online medium, students and teachers are undeniably no longer require direct face-to-face meetings. From the positive side, this is good because online learning saves costs and promotes the fact that learning can happen anywhere. However, one thing that should not be overlooked by teachers and students is the fact that interpersonal skills may no longer be considered as important during online learning occasions.

Besides that, Islam is very concerned with aspects of communication and interaction among humans, and even considers that the teachers' smiles and salutations are important in the learning process. In addition, learning without the presence of teachers as guides may also result to impaired interaction. Two-way communication becomes somewhat ineffective because the importance of courtesy and decorum during the learning process with teachers is forgotten and considered as unimportant. Some students may use improper language, phrases, salutations or even emoticons when discussing with peers and teachers in social media platforms. Unfortunately, these are among the risks of learning through the online medium.

\section{The credibility of information is becoming doubtful.}

Media credibility is a quality that becomes a measure of trustworthiness when accessing online resources. The credibility of information obtained from the internet may become doubtful due to unclear sources of reference, lack of information dissemination, and inappropriate use of language. As a result, the quality of knowledge gained is low, especially those related to knowledge of Islam. In fact, it is also feared that the knowledge about Islam obtained through the internet is misleading from its true meaning. 
Vol. 8, No. 1, 2019, E-ISSN: 2226-6348 @ 2019 HRMARS

Islam encourages quests for knowledge and promotes the innovation of science and technology. Most importantly, the transformation of education through digital media should not separate teachings related to divinity, morality, ethics in line with the development of today's world (Rashed \& Tamuri, 2015). Muslims from all walks of life, whether they are teenagers, elders, parents, students, teachers, administrators, politicians, or professionals have to be alert towards the risks of using the new media.

\section{Advantages of New Media to Young Students}

The positive effects of using new media to students as they are easily influenced and affected would include:

\section{Education}

Contemporary education becomes more versatile with the existence of flexible learning programmes, virtual classrooms, and virtual learning partners; as a result, education can cater to everyone's needs, whether the young or old. Today, there is even the concept of a virtual university, a university without traditional classrooms. Nevertheless, with regards to the virtual classrooms, it is needed to take a heed that in Islam, there is a concept of science integration which is based on the integration of faith and knowledge, body and spirit, mind and heart, intellect and revelation. Therefore, the emphasis on physical, emotional, spiritual, and intellectual elements should be prioritized in education especially when using the new media. In Malaysia, the young ones should be nurtured and taught with virtuous and humble values and practice good society traditions.

\section{Cultivator of Knowledge}

Knowledge can be nurtured by implementing proper usage of the new media. In line with the Al-Quran and Al-Sunnah, the value of Iqra or knowledge should be highlighted and repeated. A knowledgeable society will be able to maintain their existence and survival; whereas those who do not make science as the main element in their lives would be easily manipulated by others.

\section{Information Store}

Nowadays, due to high penetration of the internet by all ages of Malaysian citizens, even young students can easily access information and knowledge wherever and whenever. Teenagers, aged from thirteen years old to twenty-one years old, are at a reasonable age to seek and gain knowledge through the new media medium. Hence, it is important for teachers and parents to teach and guide youngsters to filter information obtained from the internet. This is to ensure that the young ones could identify and differentiate genuine and fake information. Information search engines must be reviewed and obtained information must be filtered. These actions must be guided by religion so that youngsters are able to benefit from the use of modern technology at the utmost optimum level (Salahudin et al., 2006). 


\section{Communication}

Youngsters nowadays use the interactive virtual network as platforms to communicate and discuss. Sharing understanding and meaning becomes faster when the basics of communication are mastered. With the use of the new media, the meaning of communication that refers to the sharing of meaning and understanding can be translated, thus the spread of attitude, emotion, meaning, and behaviour in communication is successful (Aini \& Salahudin, 2012)

\section{Ethics in Using New Media Technology in Islamic Perspectives}

Muslims have a duty to learn the ethics of using the new media according to Islamic perspectives. Generally, conventional and Islamic ethics share some common principles such as the elements of trust, responsibility, equality, respect and so on. Furthermore, the most closely related ethical term used in the Qur'an is khuluq: "And that thou art indeed a noble character" (Al-Qalam 68: 4). The use of new media technology has to be in accordance to the Islamic principles in line with the acts of worship and as means of cultivating faith. Therefore, the ethics of using the new media outlined by Islam are as follows:

\section{Do's and Don'ts: Right Intentions and Actions}

Tasks that follow good intentions are considered as a major requirement of a general practice of worship. Therefore, the Prophet Muhammad (peace be upon him) said:

"Every practice depends on its intention" (Hadith History of Bukhari and Muslim from

Amir al-Mukminin Umar Al-Khattab)

Using the new media can also be considered as acts of worship, if one's intentions and actions are right. On the other hand, if one of the intentions or actions is wrong, the act is not beneficial at all; and worse, it would be considered as a sin if both the intentions and actions are wrong. Intention and action contingencies are as follows:

Table 1: Contingencies of Intentions and Actions

\begin{tabular}{|c|c|c|}
\hline & $\begin{array}{c}\text { Right } \\
\text { Action }\end{array}$ & Wrong Action \\
\hline Right Intention & Devotion & Astray \\
\hline Wrong Intention & Astray & Defiant \\
\hline
\end{tabular}

Adapted from Mohammad Yusof et al. (2007) 


\section{i. Right Intention / Right Action: Devotion}

This is the best of act and will truly be rewarded by Allah. To illustrate, if teachers and students use new media in their teaching and learning and ensure that they incorporate genuine and truthful knowledge as well as maintaining the ability to communicate and benefiting others, they are devoting their teaching and learning according to Islamic paths and Allah's commands.

\section{ii. Right Intention / Wrong Action: Astray}

Although the intention is good but, it is carried out with the wrong action. This does not justify that the action is acceptable in the eyes of God as the action is still considered as wrong and can be considered as a sin if it violates others. For example, uploading a true story on social sites as a lesson to the community; however, if the story ended up insulting or humiliating a person, then such an action is considered as wrong and astray from Islamic paths.

\section{iii.Wrong Intention / Right Action: Astray}

The use of digital media as a medium of teaching and learning by spreading Islamic information is a praiseworthy act. However, this would also turn into a sin, if the actual intention of the individual is wrong, such as trying too much to be seen as someone who is wise on the social media, but the individual is actually someone who is spreading misguided Islamic information to others.

\section{iv.Wrong Intention / Wrong Action: Defiant}

Certain irresponsible people use the media with wrong intention and action. Examples of such people are those who would sabotage others by posting false information, insulting, slandering, and altering information intentionally. These acts are clearly sinful for being hurtful and cruel to others. Therefore, knowledge should be practiced truthfully and not based on speculation (Akademi Pengurusan YAPEIM, 2010).

\section{Using Social Media to Achieve Al-Falah}

Al-Falah is the success and well-being of human life which included physical well-being and peace which can be achieved through the balance of one's emotional and material needs (Mohamad \& Ahmad, 2013). New media users should embed the value of al-falah when using new media platforms. The use of new media for teaching and learning, business, and communication must be done for positive purposes and goals to ease one's success and well-being in the world and the hereafter. Features of success in today's world are mostly depended upon "one who knows, one who is fast and one who is efficient" (Othman, 2000).

\section{Practice Justice in Receiving and Giving Information}

When using the new media, one should practice justice especially, when uploading or downloading any information. Justice here means that the information is not simply being changed for one's own benefits, and the information and resources are unbiased and without containing any biased personal interests. This adheres to God's commands:

"O ye who believe! Be ye all steadfast in the cause of Allah, for the truth; and never let your hatred against a person induce you to not do justice. Be fair (to anyone) because 
INTERNATIONAL JOURNAL OF ACADEMIC RESEARCH IN PROGRESSIVE EDUCATION AND DEVELOPMENT

Vol. 8, No. 1, 2019, E-ISSN: 2226-6348 @ 2019 HRMARS

fairness is closer to the taqwa. And be careful of Allah, surely Allah is well-acquainted with what you do. "(Al-Mā'idah 5: 8)

\section{Practice Balance (Tawazun)}

All Islamic teachings are tawazun, which means having a balance in all aspects of life. Islam prohibits over-extremism. Islam permits the use of new media technology as long as it does not violate any sharia restrictions. Therefore, new media users must be able to practice balance when they are online to avoid harm. For example, several incidents from abroad have recorded death cases due to excessive playing of computers; thus, this is the best example of the effects of ethical neglect. Moreover, users of the new media are exposed to various risks such as internet abuse, illicit social affairs, hacking and other negative practices. Good ethics such as having balance in using digital media are useful to control the behaviour of digital media users to ensure that users minimize and avoid any potential disaster.

\section{Maintaining Human Relations with Others}

The new media must be used as a tool to promote healthy and positive human relationships and must not be used in ways which can set humans apart. For example, society's right is should not be harmed in the name of freedom. Family members' rights are absolutely irreplaceable. The family relationship can fade when family members are too preoccupied or obsessed with mobile phones. Finally, the rights of a colleague must also be upheld and respected. Colleagues must not insult and look down upon their peers.

\section{Keeping Maqasid (Goals/ Purposes)}

Keeping maqasid syariah or purpose of syariah is a core point in a Muslim's life. Hence, the use of the digital media should not overlook this element. A person must not use digital media as a tool to attack an individual's personality, disgrace others, and make use of digital technology to make profits which are not allowed in Islam.

\section{Reasons on Why Ethics of Using New Media Should be Learnt}

The ethics of using the digital media need to be upheld not only by Muslims, but by those who believe in living in a respectable and progressive society and nation (Mohammad Yusof et al., 2007). Learning the ethics of using the digital media is necessary for the following reasons: 1. A person is able to have the awareness, knowledge and skill to control his or her behaviour and use the new media for the common good of all.

2. A person can discipline himself or herself to have good ethics to know whether their actions are moral or immoral when using the new media.

3. A person is able to manage time wisely, be wise in accessing positive contents and websites, socialise well in any social environments, choose friends who are positive in social media platforms and avoid being cyber bullies, scammers, haters and negative keyboard warriors when surfing online.

4. A person is able to regard and viral only positive issues in order to uphold a positive environment for young and adult users (Manap et al., 2016).

5. Society can become more knowledgeable and positive. Positive elements such as respecting others, establishing good relations, having compassion, asking respectfully, and other positive 
DEVELOPMENT

Vol. 8, No. 1, 2019, E-ISSN: 2226-6348 ๑ 2019 HRMARS

ethics should be learned and practised by individuals in our modern society. Ethics and moral principles are the driving force behind the creation and use of technology that can enhance the well-being of life (Mohammad Yusof et al, 2017).

\section{Conclusion}

It is important to note that new media should not be separated from today's education as it is interrelated with all aspects of human life which is associated with the new advanced technology. In fact, new media is widely used to promote aspects of interpersonal communication and education. Nevertheless, ignorance, abuse and poor management of new media usage among its users may lead to negative implications. Therefore, parents and educators must ensure that they have a high level of awareness, and become transparent and open minded with regards to the use of new media and advanced digital technology before allowing children and youngsters to have the freedom to use the gadgets and internet technology. Without proper monitoring and control, young students may get addicted and obsessed with such technologies. It is hoped that the tips and guidance proposed in this paper serve to help contemporary technology users to embrace these technologies respectably and responsibly. This is very important in order to grasp the many transformations in the education experiences that can be fulfilled in the hands of great parents and teachers. Significantly, this paper contributes to the principles of using new media in education.

\section{Corresponding Author}

Juritah Misman, Akademi Pengajian Bahasa, Universiti Teknologi MARA Cawangan Melaka, KM26 Jalan Lendu 78000 Alor Gajah, Malaysia

Email: juritah744@melaka.uitm.edu.my

\section{References}

Aini, Z. \& Suyurno, S. S. (2012), Asas Komunikasi Dakwah. Bandar Seri Putra, Selangor: KUIS.

YAPEIM, A. P. (2010). Pengurusan Islami Menghayati Prinsip dan Nilai Qurani. Kuala Lumpur: Akademi Pengurusan Yapeim Sdn. Bhd.

Manap, J. (2016). Penggunaan dan Implikasi Media Sosial Terhadap Generasi Z. In International Conference on Social and Economic Development (ICSED) 2016. Universiti Malaysia Terengganu, Malaysia.

Mohamad, N. S. \& Ahmad, S. (2013) Development from Islamic Perspective: An Interim Analysis. Proceeding PERKEM VIII, 1, $355-370$.

Mohammad Yusof, Z. (2007) Teknologi Maklumat dan Komunikasi: Etika, Undang-undang dan Sosial (Edisi ke-2). Shah Alam: McGraw-Hill.

Mohammad Yusof, Z. (2017). Adab Mengguna Media Sosial. Paper presented at Seminar Antarabangsa Dakwah Ke-3. Bangi, Selangor: Universiti Kebangsaan Malaysia. 
INTERNATIONAL JOURNAL OF ACADEMIC RESEARCH IN PROGRESSIVE EDUCATION AND

DEVELOPMENT

Vol. 8, No. 1, 2019, E-ISSN: $2226-6348$ @ 2019 HRMARS

Othman, M. (2000). Sekolah Bistari-Perspektif Islam. In Siti Fatimah Abdul Rahman (Ed.) Multimedia dan Islam. Kuala Lumpur: Institut Kefahaman Islam Malaysia.

Rashed, Z. N. \& Tamuri, A. H. (2015) Kepentingan Integrasi Ilmu Naqli dan Ilmu Aqli dalam Pengajaran Pendidikan Islam, E-Jurnal Pendidikan, 2 (1), 5-14.

Ramlan, A. F. \& Ridzuan, A. R. (2016). Cabaran Pekembangan Teknologi Komunikasi Terhadap Pembentukan Liberalisasi Budaya dalam Kalangan Generasi Muda. In Siti Nasarah Ismail \& Dzaa Imma (Eds.) Islamisasi Media. Shah Alam, Selangor: Penerbit UiTM.

Saifee, A. (2012). The Role of Mass Media \& Information Technology in Islamic Education. European Journal of Social Sciences, 32(2), 380-390.

Suyurno, S. S. (2006), Sains dan ICT: Peranan \& Cabaran Menurut Perspektif Islam. Shah Alam: UPENA. 